\title{
ARSENIASIS AS AN ENVIRONMENTAL HYPOTHETICAL EXPLANATION FOR THE ORIGIN OF THE OLDEST ARTIFICIAL MUMMIFICATION PRACTICE IN THE WORLD
}

\author{
ARSENICISMO, UNA HIPÓTESIS MEDIOAMBIENTAL PARA EXPLICAR EL \\ ORIGEN DE LA MOMIFICACIÓN MÁS ANTIGUA DEL MUNDO
}

\author{
Bernardo T. Arriaza*
}

\begin{abstract}
This essay explores the idea that arsenic poisoning was the impetus for the origin of the oldest mummification practice in the world. The Chinchorro people artificially mummified fetuses and infants starting 7000 years ago, but we do not know why. The

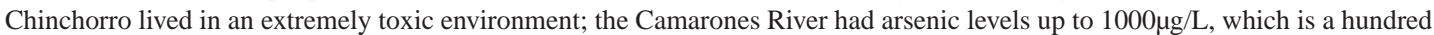
times the modern safety level. Chronic exposure to arsenic produces spontaneous abortions and preterm births. Interestingly, the earliest Chinchorro mummies are all infants. Under these environmental conditions, the Chinchorro miscarriage rate was likely 30 times higher than any other Andean population. Thus, arseniasis is a plausible environmental hypothesis to explain the origin of the Chinchorro's unique mortuary practice and infant mummification. In other words, Chinchorro mortuary practice began as a cultural response to an environmental phenomenon that was deadly to the population.
\end{abstract}

Key words: Arseniasis, fetal health, artificial mummification, spontaneous abortions, stillbirths, infant mortality.

En este ensayo se postula que el origen de la momificación de los Chinchorro, la más antigua del mundo, fue provocado por un envenenamiento crónico con arsénico. Hace 7.000 años la gente Chinchorro comenzó a momificar intencionalmente a fetos e infantes y no sabemos por qué. Los Chinchorro vivían en un medio ambiente extremadamente tóxico con aguas de río que contienen niveles de arsénico de $1.000 \mu \mathrm{g} / \mathrm{L}$, es decir, 100 veces más de los niveles recomendados para la salud. El arsenicismo produce abortos espontáneos y el nacimiento de niños prematuros y resulta interesante que las primeras momias Chinchorro son todos infantes. Entonces el arsenicismo trajo como consecuencia que las mujeres Chinchorro tuvieran tasas de abortos probablemente 30 veces más altas que cualquier población. Se postula entonces que arsenicismo es una posible hipótesis medioambiental que explicaría el origen de esta singular práctica de momificar a los muertos y porque comienzan a momificar a los infantes. Es decir, esta práctica de momificar a los muertos surgió como una respuesta cultural frente a un fenómeno medioambiental que diezmaba a la población.

Palabras claves: arsenicismo crónico, salud del feto, momificación artificial, abortos espontáneos, nacidos muertos, mortalidad infantil.

Chinchorro was a pre-ceramic culture that contrary to expectations developed complex mummification systems starting about 5000 B.C. (Arriaza 1995; Aufderheide et al. 1993; Standen 1997). The dead were transformed into statue-like figures by adding sticks, clay, and mineral pigments to human skin and bones. Scholars have debated how and where Chinchorro artificial mummification developed (Allison et al. 1984; Arriaza 1985; Standen 1997); but the question of why has remained unanswered for nearly a hundred years. The first Chinchorro mummies were those of children (Schiappacasse and Niemeyer 1984). Here, it is shown that arseniasis is a plausible and testable hypothesis to explain the origin of this unique prac- tice. The Chinchorro began to mummify their dead in the Camarones Valley in northern Chile where the Rio Camarones has on average $1000 \mu \mathrm{g} / \mathrm{L}$ arsenic levels (Cornejo 2004; Figueroa 2001:8). This is a hundred times in excess of $10 \mu \mathrm{g} / \mathrm{L}$, the standard deemed acceptable by the World Health Organization (http://www.who.int/mediacentre/factsheets/fs210/en/). Chronic exposure to arsenic produces spontaneous abortions, stillbirths, and preterm births (Ahmad et al. 2001; Centeno et al. 2002). Arseniasis threatened group survival, and as an emotional response Chinchorro people likely created artificial mummification to assuage their social grief. The importance of this essay lies in debating how endemic elemental hazards affected

\footnotetext{
* Departamento de Antropología; Centro de Investigaciones del Hombre en el Desierto, Universidad de Tarapacá, Casilla 6D, Arica, Chile.barriaza@uta.cl
} 
the health of ancient people and shaped them culturally as well.

Environment and culture shape societies. Poisons affect our health and behavior, and do so especially when they occur endemically and in high concentrations. Medium to high arsenic levels are common in the drinking water of the coastal areas of northern Chile from Arica to Antofagasta (Figueroa 2001; Hopenhayn et al. 2000). However, the narrow coastal oasis of Camarones has the highest modern levels of arsenic in the area, and is birthplace of these life-size mummy-figures. Camarones' water has an arsenic concentration of $1000 \mu \mathrm{g} / \mathrm{L}$, while nearby Lluta valley has a concentration of $200 \mu \mathrm{g} / \mathrm{L}$ (Figueroa 2001). Arsenic is a naturally occurring toxic element hazardous to humans. Arseniasis produces hyperpigmentation of the skin, keratosis, and systemic diseases including carcinomas of the liver and bladder (Ahmad et al. 2001; Centeno et al. 2002). Keratosis and skin cancers related to arseniasis (Figueroa 2001; Figueroa et al. 1988) have affected modern and Inka people (ca. 1400 A.D.) of the Camarones valley of northern Chile. However, despite prehistoric evidence of arseniasis, no archeological studies have focused on its possible impact on reproduction and infant mortality.

The fact that the oldest human-made mummies in this area come from the Camarones 14 site (Schiappacasse and Niemeyer 1984) and are all infants and children is intriguing and deserves a closer examination. Using clinical and bioarchaeological data, an environmental model is proposed here to explain how environment, health, and culture interconnect (Figure 1).

Camarones is a narrow and shallow river. Notwithstanding its high arsenic content, this oasis provided food for the early inhabitants that populated this area for thousands of years. The Chinchorro were small groups of fisher folk living in this extremely toxic environment. Figueroa (2001) reported that arsenic was present in the food and the plants they used for bedding, clothing, and shelter. Autopsies of late Camarones mummies (ca. 1500 A.D.) revealed keratosis and high levels of arsenic in various bodily tissues. In addition, the Chinchorro people had infant mortality rates ranging from 21-26\% (Arriaza 1995; Schiappacasse and Niemeyer 1984). Today, we know extreme arseniasis in the range of $800 \mu \mathrm{g} / \mathrm{L}$ severely affected fetal growth and dramatically increased rates of stillbirth and infant mortality in Antofagasta (about $600 \mathrm{~km}$ south of Camarones) between 1960-1970 (Hopenhayn et al. 2000). The city's dwellers were drinking arsenic-contaminated water supplied by the Toconce River. In the seventies, an arsenic removal plant reduced the toxic levels to $40 \mu \mathrm{g} / \mathrm{L}$. However, despite lower levels today, another study of 424 Chilean infants from Antofagasta suggests a clear link between water quality and low birth weight (Hopenhayn et al. 2003). Antofagasta infants have significantly lower birth weights than their southern Chilean counterparts - a consequence of pregnant mothers' consuming water contaminated with arsenic levels four times higher than recommended levels. Arsenic levels in water in Antofagasta are $30-40 \mu \mathrm{g} / \mathrm{L}$ while in central Chile it is $<1 \mu \mathrm{g} / \mathrm{L}$ (Hopenhayn et al. 2000; 2003).

Offspring chronically exposed to high levels of arsenic have increased mortality. In addition to decreased birth weight of newborns, arseniasis complications in children include mental retardation and systemic organ damage leading to low red blood cell production, skin keratosis, and bladder and liver cancer (Ahmad et al. 2001; Centeno et al. 2002; Figueroa 2001). Children exposed to more than five years of chronic arsenic may develop angiosarcoma (Centeno et al. 2002). Given these environmental and pathophysiological facts, there is no doubt that Chinchorro women from Camarones faced many miscarriages. High rates of miscarriage and infant mortality directly threatened the small Camarones Chinchorro fishing villages. In this life threatening and population bottleneck, reproductive scenario, Chinchorro parents, especially mothers, faced an increasing social pressure to produce children who could survive. A biocultural link between the development of artificial mummification and arseniasis is plausible.

Generally, artificial mummification is associated with hierarchical societies with socio-political complexity and intense social competition. Chinchorro anthropogenic practices began in the Camarones Valley about 5000 B.C. and endured until about 1100 B.C. This was a truly unexpected cultural phenomenon for a pre-ceramic society, not only for the antiquity and complexity of the mummies, but because the dead were transformed into artistic figures (Arriaza 1998). Chinchorro subsistence was based on fishing, and hunting marine mammals. Technologically, they were quite simple; they relied on reeds to make baskets, clothes, 


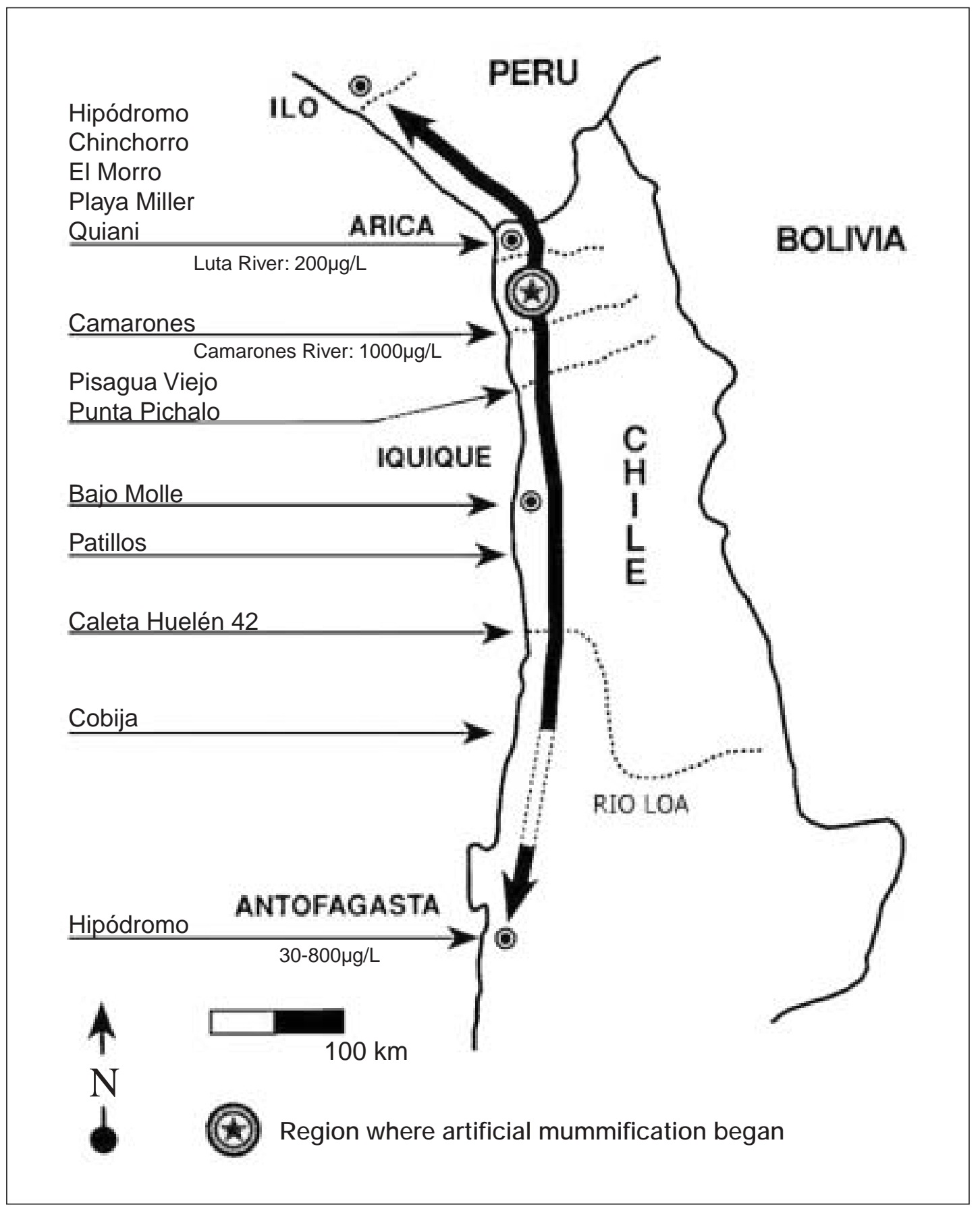

Figure 1. Map of the region showing Chinchorro sites, in water supplies and arsenic levels. Sitios Chinchorro y niveles de arsénico en fuentes de agua.

and fishing gear. Lithic knives and small harpoons complemented their tools. The Chinchorros lacked ceramics, metals, and woven textiles, yet they developed one of the most intriguing mummification practices in the world. It is very likely that there was a connection between high environmental arsenic levels and the origin of mummification, with arseniasis triggering Chinchorro mortuary practices. 
Chinchorro's captivating mortuary tradition transformed the corpses into human effigies. From the Camarones Valley, this mortuary custom spread north and south, covering about $900 \mathrm{~km}$ along the Atacama Desert and the Pacific coast. Corpses were defleshed and were reassembled using sticks, clay, and mineral pigments added to human skin and bones. Facial and sexual organs were modeled and subsequently the complete body was carefully painted with manganese. The final product was a rigid and shinny black body, the so-called black mummies (Arriaza 1995; Arriaza and Standen 2002). As the centuries went by mummification was applied to individuals of all ages, including human fetuses, and the techniques changed dramatically. The complete body except the face and wig was painted with a bright red ochre pigment that was sometimes burnished. Facial characteristics were modeled, emphasizing open eyes and mouth, as if the body was conveying life, and breathing. These red mummies first appeared around 2000 B.C. and continued for almost 500 years (Figures 2-4).

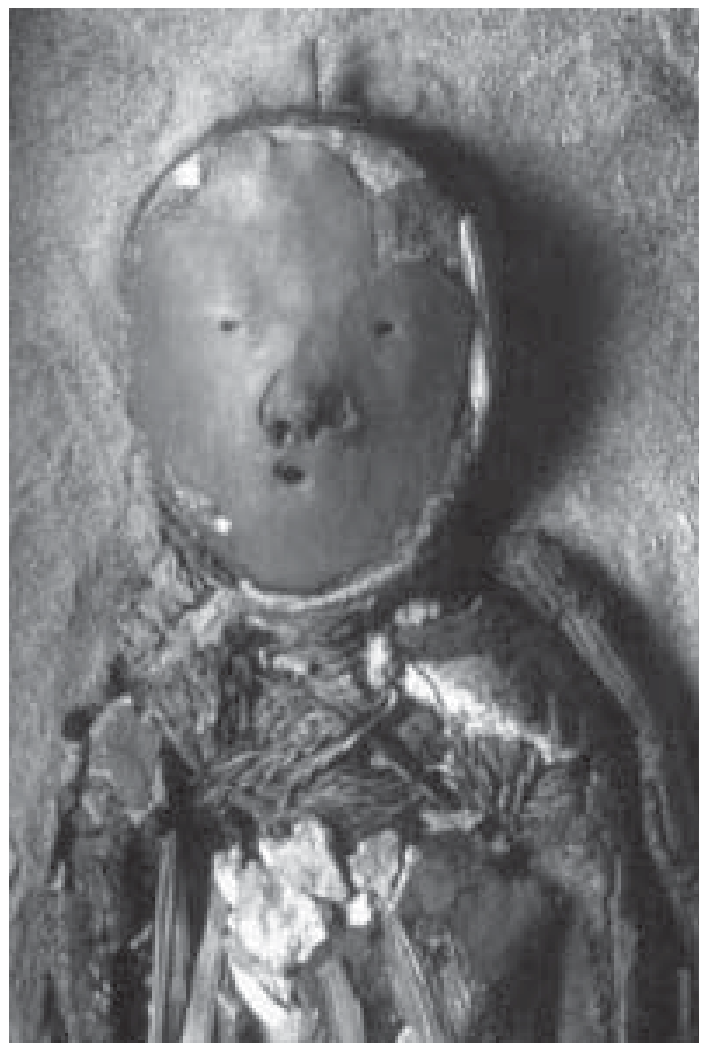

Figure 2. Chinchorro child, black style. Niño Chinchorro momificado estilo negro.
The minimal literature debating why the Chinchorro people developed artificial mummification can be summarized into three basic propositions (Arriaza 1995).

- Religion. Bodies were mummified because the Chinchorro people believed in the afterlife and in the duality of body and soul. Preservation of the body was essential for continuity of the soul, as well as life in the world beyond. This spiritual ideology is also seen in the Egyptian and Inka empires. Religious ideology, as a reason for mummification, is certainly a possible hypothesis, and is likely a secondary effect of the arseniasis model presented here.

- Social rank. Artificial mummification is often used as a sign of higher rank. Generally, not everyone is accorded mummification, and even in the cases where they are, upper-class individuals receive a more complex and elaborate mortuary treatment. Complex mortuary treatments, including artificial mummification, are common in many highly stratified societies. However, it is unlikely this was the case for the Chinchorros. They were not a highly stratified society; fetuses, newborns, and young and old males and females were mummified.

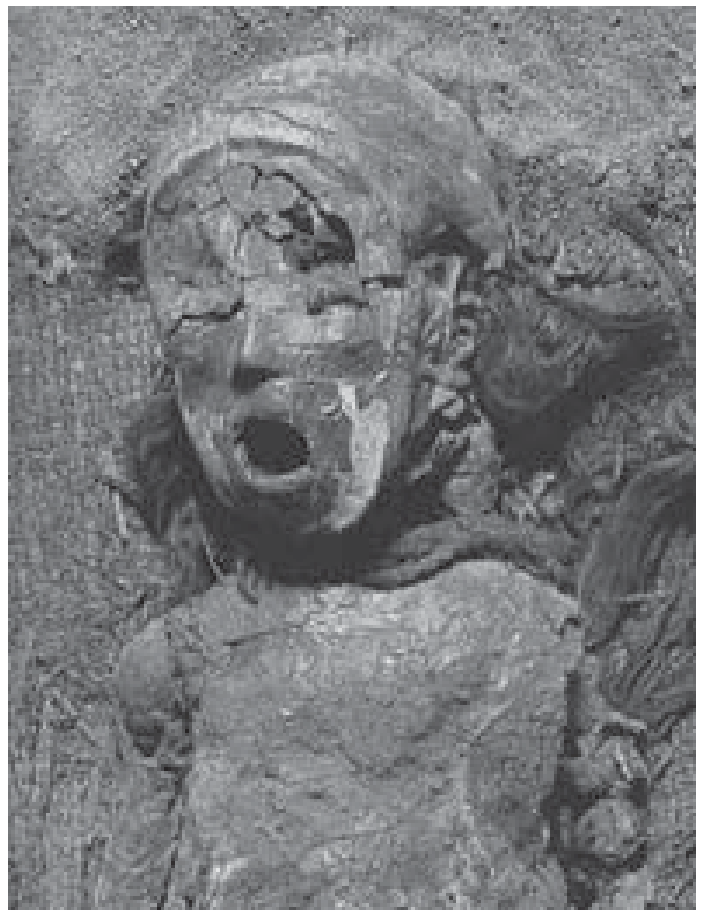

Figure 3. Chinchorro child, red style. Niño Chinchorro momificado estilo rojo. 


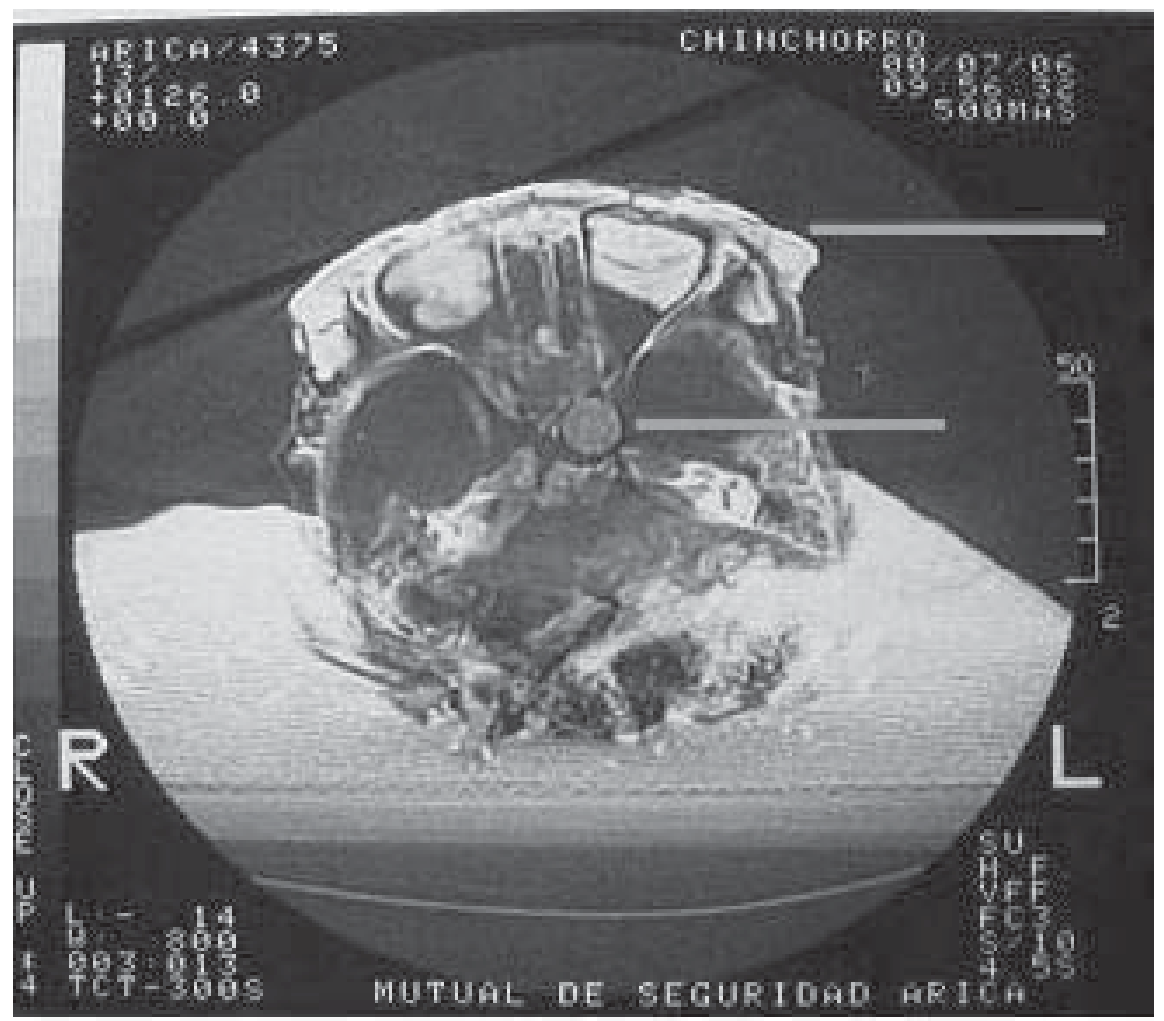

Figure 4. CT-scan sectional view of a Chinchorro child's head. See clay mask (top arrow) and stick at the base of the skull (lower arrow). Escaner de la cabeza de un niño Chinchorro. Nótese la mascarilla de arcilla (flecha superior) y un madero en la base del cráneo (flecha inferior).

- Love of children. Chinchorro mummification started with children. High infant mortality perhaps triggered loving mothers to preserve their babies, to keep them above ground and in their presence. Most ancient cultures exhibit high infant mortality. Even today high infant mortality is common in Third World countries. However, few cultures have developed artificial mummification; however, again this may be a valid motivator though not stimulus in the arseniasis model presented here.

The environmental hypothesis presented can be tested in the bones of infants and fetuses. Additionally, it provides a better explanation than the three previous models. Arsenic is a carcinogen and has mutagenic and teratogenic effects at toxic levels. In pregnant women, it crosses the placenta affecting fetal development, which increases the risk of spontaneous abortions, stillbirths, preterm births, and low birth weight (Ahmad et al. 2001; Centeno et al. 2002; Figueroa 2001; Hopenhayn et al. 2000; 2003). In a population affected by arseniasis the rate of miscarriages is high. Ahmad et al. (2001) in a study of 192 women in Bangladesh of reproductive age (15-49 years) who were drinking water with $100 \mu \mathrm{g} / \mathrm{L}$ of arsenic reported rates nearly three times greater for spontaneous abortion when compared with women of the same age, who had no exposure to arsenic in their drinking water. In addition, these exposed women had more than double the rates of stillbirths and preterm births compared to their unexposed counterparts. When these same women were exposed to these conditions for 15 years or more the rates increased about five times. Assuming a linear relationship between arsenic levels and health impact and extrapolating these figures to the $1000 \mu \mathrm{g} / \mathrm{L}$ of arsenic at Camarones, Chinchorro women likely had rates 30 times higher for spontaneous abortion, stillbirths, and preterm births.

At the Camarones 14 cemetery, of twenty-three excavated individuals, the oldest ones found so far are four infants, with a crude style of the classic Chinchorro mummification practice (sticks along 
the extremities, wig, and clay) that date to about 5000 years B.C. Moreover, 70 years later, the same pattern of mummified infants appeared at the nearby Camarones 17 site (Aufderheide et al. 1993). Here the spontaneously or naturally mummified body of an adult female was found buried with three artificially mummified infants. Centuries later this anthropogenic mortuary practice had moved north about 100 kilometers and was flourishing in Arica and surrounding areas.

Thus, in summary, the genesis of Chinchorro artificial mummification, at Camarones, was likely multifactorial. The model leading to artificial mummification can be sketched as follows. The dryness of the Atacama Desert allowed for the observation of naturally preserved corpses of humans and animals. Small bands of Chinchorro people living with toxic environmental levels of arsenic, exposed, and predisposed themselves to high rates of miscarriages, stillbirths, and infant mortality. This significantly affected group survival and popula- tion growth. Thus, as a social and emotional response to losing many of their fetuses and infants, Chinchorro parents created artificial mummification to assuage their collective grief. In this way, their infants could remain physically with them as beautifully decorated bodies. Over time, the practice spread to the rest of the population. In conclusion, it is reasonable to infer that Chinchorrro artificial mummification was triggered by toxic arsenic levels and shaped by human grief and emotional needs for extended mortuary rituals. It was a powerful and sympathetic cultural practice enduring for nearly four millennia.

Acknowledgement: I thank the financial support given by the USA-Chilean Fulbright Commission Fellowship 2002-2003 and the University of Nevada-Las Vegas, sabbatical leave, 2002-2003. I am grateful to Vicki Cassman, Luz Pfister, Michelle Kaye and all the anonymous reviewers for critical comments of this manuscript.

\section{References Cited}

Ahmad, SA, M.H.S. Sayed, S. Barua, M.H. Khan, M.H. Faruquee, A. Jalil, S.A. Hadi, and H. Kabir

2001 Arsenic in drinking water and pregnancy outcomes. Environ Health Perspect 109:629-631.

Allison, M., G. Focacci, B. Arriaza, V. Standen, M. Rivera, and J. Lowestein

1984 Chinchorro, momias de preparación complicada: métodos de momificación. Chungara 13:155-173.

Arriaza, B.

1995 Beyond Death. The Chinchorro Mummies of Ancient Chile. Smithsonian Institution Press, Washington D.C.

1998 South American mummies culture and disease (Chinchorro section). In Mummies, Diseases and Ancient Cultures, edited by A. Cockburn. E. Cockburn, and T. Reyman, pp. 190-197. Cambridge University Press, Cambridge.

Arriaza, B. and V. Standen

2002 Momias, Muerte y Ritos Ancestrales. Ediciones Universidad de Tarapacá, Arica.

Aufderheide, A., I. Muñoz, and B. Arriaza

1993 Seven Chinchorro mummies and the prehistory of northern Chile. American Journal of Physical Anthropology 91:189-201.

Centeno, J., F.G. Mullick, L. Martinez, N. Page, H. Gibb, D. Longfellow, C. Thompson, and E. Ladich

2002 Pathology related to chronic arsenic exposure. Environ Health Perspect 110 (suppl 5):883-886.

Cornejo, L.

2004 Reducción de la concentración de arsénico en agua de consumo humano en zonas rurales. Paper presented at the Encuentro sobre uso y resultados de la aplicación de tec- nologías económicas para la purificación de aguas en América Latina. Proyecto OEA/AE 141. November 8th and 9th. Centro Atómico Constituyentes, Comisión Nacional de Energía Atómica, Prov. de Buenos Aires, Argentina.

Figueroa, L.

2001 Arica Inserta en una Región Arsenical: El Arsénico en Ambiente que la Afecta y 45 Siglos de Arsenicismo Crónico. Ediciones Universidad de Tarapacá, Arica.

Figueroa, L., B. Razmilic, M. Allison, and M. Gonzales

1988 Evidencia de arsenicismo crónico en momias del Valle de Camarones. Región de Tarapacá, Chile. Chungara 21:33-42.

Hopenhayn-Rich, C., S. Browning, I. Hertz-Picciotto, C. Ferreccio, C. Peralta, and H. Gibb

2000 Chronic arsenic exposure and risk of infant mortality in two areas of Chile. Environ Health Perspect 108:667-73.

Hopenhayn, C., C. Ferreccio, S. Browning, B. Huang, C. Peralta, H. Gibb, and I. Hertz-Picciotto

2003 Arsenic exposure from drinking water and birth weight. Epidemiology 14:593-602.

Schiappacasse F. and H. Niemeyer

1984 Descripción y análisis interpretativo de un sitio arcaico temprano en la Quebrada de Camarones. Publicación Ocasional $\mathrm{N}^{\circ}$ 41. Museo Nacional de Historia Natural. Santiago.

Standen, V.

1997 Temprana complejidad funeraria en la cultura Chinchorro: Norte de Chile. Latin American Antiquity 8:134-156. World Health Organization.

2005. Http://www.who.int/mediacentre/factsheets/fs210/en/ 